\title{
В.І. Козявкін ${ }^{1}$, В.І. Цимбалюк ${ }^{2}$ В.В. Медведєв, О.А. Рибачук ${ }^{4,5}$, Н.Г. Драгунцова ${ }^{2}$ \\ ВПЛИВ ОБМЕЖЕННЯ СПОНТАННОЇ ЛОКОМОТОРНОЇ АКТИВНОСТІ НА ПЕРЕБІГ СИНДРОМУ СПАСТИЧНОСТІ ЗА УМОВИ ЕКСПЕРИМЕНТАЛЬНОЇ ТРАВМИ СПИННОГО МОЗКУ ТА ІМПЛАНТАЦЇ̈ МАТРИКСУ NEUROGEL ${ }^{\text {TM }}$, АСОЩЙОВАНОГО 3 НЕЙРОГЕННИМИ СТОВБУРОВИМИ КЛІТИНАМИ
}

\author{
${ }^{1}$ Міжнародна клініка відновного лікування, м. Трускавець \\ 2 ду "Інститут нейрохірургії ім. акад. А.П. Ромоданова НАМН України", м. Київ \\ ${ }^{3}$ Національний медичний університет імені О.О. Богомольця, м. Київ \\ ${ }^{4}$ Інститут фізіології імені О.О. Богомольця НАН України, м. Київ \\ ${ }^{5}$ ДУ "Інститут генетичної та регенеративної медицини НАМН України", м. Київ
}

\begin{abstract}
Резюме. Мета: дослідити вплив імплантації Neu$\operatorname{roGel}^{\mathrm{TM}}$, асоційованого 3 нейрогенними стовбуровими клітинами (НСК), у поєднанні з лібералізацією спонтанної локомоторної активності на відновлення рухової функції та динаміку спастичності паретичної задньої кінцівки щура після травми спинного мозку.

Матеріал і методи. Тварини - білі безпородні щури-самці (5 міс., 250 г); групи: 1 - травма спинного мозку $(n=16) ; 2$ - травма спинного мозку + гомотопічна імплантація фрагмента NeuroGel ${ }^{\mathrm{TM}}(n=20) ; 3$ - травма спинного мозку + гомотопічна імплантація фрагмент $\mathrm{NeuroGel}^{\mathrm{TM}}$, асоційованого з НСК фетального гіпокампа миші $(n=20)$. Група 3 включала підгрупу $3_{\text {мк }}(\mathrm{n}=11)$, тварин якої протягом експерименту утримували в клітках малого розміру $(30 \times 20 \times 10 \mathrm{~cm})$, та підгрупу $3_{\text {вк }}$ $(\mathrm{n}=9)$, тварин якої утримували в клітках великого розміpy $(40 \times 30 \times 15 \mathrm{~cm})$. Модель травми - лівобічний перетин половини спинного мозку на рівні $\mathrm{T}_{11}$; тривалість спостереження - 28 тиж.; оцінка показника функції (ПФ) та показника спастичності (ПС) задньої іпсилатеральної кінцівки (ЗІК) - шкала Basso-Beattie-Bresnahan (BBB) та Ashworth, відповідно.
\end{abstract}

Результати. Обмеження спонтанної локомоторної активності сповільнює відновлення рухової функції

Вступ. Відновлення функції спинного мозку після його травматичного ураження є однією 3 найскладніших біомедичних проблем $[7,10,20$, $26,36]$, вирішення якої пов'язують із прогресом тканинної нейроінженерії [16, 30, 37, 38], біонічного протезування $[9,15,21]$, хірургічних методів трансформації периферійної ланки рухової системи [3], хронічної електростимуляції [3], а також засобів фізичної реабілітації $[8,14,19,22$, $28,33]$.

Тканинна нейроінженерія в контексті лікування спінальної травми грунтується на створенні локальних умов для росту та мієлінізації травмованих аксонів. 3 цією метою використовують імплантацію в зону травми клітин різного походження та ступеня диференціювання в комплексі 3 матриксами - штучно створеними просторовими “каркасами” різної первинної хімічної структури, серед яких апробованими на даний час $\epsilon$ матеріали на пептидній, протеїновій, синтетичній та змішаній основі $[16,30,37,38]$. Одним із найбільш ефективних синтетичних матриксів у випадку спінальної травми $є$ макропористий гідрогель паретичної кінцівки протягом 1-го місяця, скорочує тривалість значущого відновлення у віддаленому періоді травми. Станом на 28-й тиждень спостереження ПФ ЗІК у групі $1-1,6 \pm 0,5$ бала ВBВ, у групі $2-8,4 \pm 0,9$ бала, у групі $3-13,1 \pm 0,9$ бала, у підгрупі $3_{\text {мк }}-12,6 \pm 1,4$ бала, у підгрупі $3_{\text {вк }}-13,7 \pm 0,8$ бала ВВВ. ПС ЗІК на цьому терміні у групі $1-2,5 \pm 0,4$ бала, у групі $2-$ $1,7 \pm 0,2$ бала, у групі $3-1,3 \pm 0,1$ бала, у підгрупі $3_{\text {мк }}-$ $1,4 \pm 0,2$ бала, у підгрупі $3_{\text {вк }}-1,2 \pm 0,1$ бала, Ashworth. Значущу різницю значень ПС ЗІК між групами 2 та 1 відмічали на 1-, 5-7-му та 12-24-му тижні, між групами 3 та 1 - на 1-2-, 6-7-му та 16-28-му тижні, між групами 3 та 2 - на 1-2-му та 5-му тижні, між підгрупою $3_{\text {вк та }}$

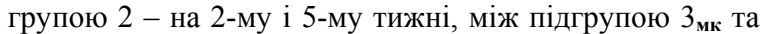

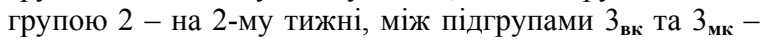
не виявили.

Висновок. Обмеження спонтанної локомоторної активності тварини в умовах тканинно-інженерного відновного втручання після спінальної травми ускладнює перебіг регенераційного процесу, пришвидшує формування стійкого синдрому спастичності.

Ключові слова: травма спинного мозку, синдром спастичності, відновна нейрохірургія, тканинна нейроінженерія, фізична реабілітація.

NeuroGel $^{\mathrm{TM}}$ з аморфною мікроструктурою $[4,13$, $25,27,31,32]$. До переліку найбільш перспективних видів клітин, застосування яких у комплексі 3 матриксами сприяє відновленню функції спинного мозку, відносять нейрогенні стовбурові клітини (НСК) [16].

На даний час засоби фізичної реабілітації, що чинять суттєвий вплив на відновлення функції паретичних кінцівок та зменшують спастичність, включають (наводимо за [28]): а) методики, спрямовані на збільшення діапазону руху в суглобах - пасивний розтяг [35], повторювані пасивні рухи кінцівкою в доступному діапазоні [12], статичні вправи 3 власною масою хворого [23], пасивний сайклінг (passive cycling) [34]; б) методики, спрямовані на покращення усвідомленої рухової активності паретичних кінцівок - курси реабілітації на біговій доріжці 3 частковим підтриманням маси пацієнта (body-weight supported treadmill training) [18], силовий тренінг максимальної інтенсивності (resistance training at maximal intensity) [29], пропріоцептивне нервово-м'язове полегшення (proprioceptive neuromuscular facilita- 
tion), іпотерапія (equine-assisted therapy), гідротерапія тощо.

Реабілітаційне лікування в різних його дієвих щодо спастичності формах призводить до ефектів, що мають електрофізіологічні кореляти, наприклад, зменшення відношення амплітуди Нхвилі та F-хвилі до М-хвилі $\left(\mathrm{H}_{\max } / \mathrm{M}_{\max }\right.$ ratio, $\mathrm{F} / \mathrm{M}$ ratio), що демонструє, відповідно, зниження провідності в системі Іа-залежного пропріоцептивного рефлексу та зниження збудливості мотонейронів [34]. Механізми таких ефектів залишаються невивченими, існуючі фрагментарні дані свідчать про посилення гальмівного супра- та пропріоспінального впливу на мотонейрони [17], зниження сенсорного входу на сегментарному рівні шляхом активації гальмівних систем заднього рогу низхідними моноамінергічними шляхами [5, 24], збільшення залежного від BDNF (brain-derived neurotrophic factor) полегшення активації КCC2 $\left(\mathrm{K}^{+} / \mathrm{Cl}^{-}\right.$cotransporter 2$)$ - ключового елемента peaлізації гальмівних впливів на мотонейрони [11]. На думку деяких дослідників, найефективнішим засобом зменшення спастичності та покращення усвідомленої рухової активності є використання реабілітаційного лікування 3 моделюванням типових для звичної локомоторної активності людини рухів [28].

Отже, ідеологія фізичного реабілітаційного впливу на перебіг синдрому посттравматичної спастичності базується на збільшенні пасивної чи усвідомленої рухової активності паретичної кінцівки, у тому числі засобами зовнішнього протезування [39], тому обмеження цієї активності після спінальної травми вірогідно чинить протилежний ефект.

На даний час не викликає сумніву твердження, що найбільш перспективними $є$ комплексні методи відновного впливу на травмований спинний мозок із залученням різних шляхів стимулювання регенерації спинного мозку.

Мета дослідження. Вивчити вплив імплантаціï NeuroGel ${ }^{\mathrm{TM}}$, асоційованого ксеногенними фетальними НСК, у поєднанні $з$ лібералізацією довільної рухової активності на відновлення рухової функції та динаміку спастичності паретичної задньої кінцівки щура після травми спинного мозку.

Матеріал і методи. Дослідження виконано 3 дотриманням існуючих норм біоетики на білих безпородних щурах-самцях (віварії ДУ "Інститут нейрохірургї імені НАМН України" та Інституту фізіології імені О.О. Богомольия НАН Украӥни), віком 5 міс., масою 250 г, утримуваних у стандартних умовах. Сформовано три експериментальні групи: "контроль" - травма спинного мозку $(n=16)$; "нейрогель" - травма спинного мозку + гомотопічна імплантація фрагмента NeuroGel ${ }^{\mathrm{TM}}(n=20)$; "нейрогель+НСК" травма спинного мозку + гомотопічна імпланта- ція фрагмента NeuroGel ${ }^{\mathrm{TM}}$, асоційованого $з$ фетальними НСК миші $\quad(n=20)$. Група "нейрогель+НСК" включала дві підгрупи: а) "нейрогель+НСК(мк)" (n=11) - тварини протягом усього періоду експерименту утримували в клітках малого розміру (малих клітках, мк); б) "нейрогель+НСК(вк)" (n=9) - тварини протягом усього періоду експерименту утримували в клітках великого розміру (великих клітках, вк). Термін спостереження - 28 тижнів.

Макропористий гідрогель NeuroGel ${ }^{\mathrm{TM}}$ (полі [N-(2-гідроксипропіл)-метакриламід]) є комерційним препаратом, синтезований у лабораторії E. Pinet (FISO Technologies Inc., Quebec, Canada) шляхом гетерогенної полімеризації та асоціації [22].

Культуру НСК отримували з тканини гіпокампа зародків миші лінії FVB-Cg-Tg(GFPU)5Nagy/ $\mathrm{J}$, трансгенної за геном зеленого білка флуоресценції. У стерильних умовах у глибоко анестезованої самки на 17-ту добу гестації вилучали плоди, в яких виділяли гіпокамп, тканину механічно дисоціювали пастерівськими піпетками різного діаметра в середовищі Neurobasal («Gibco Invitrogen», США), суспензію пропускали через нейлонові клітинні фільтри («Falcon», США) 3 діаметром пор 40 мкм, центрифугували у градієнті щільності (22\% розчин Percoll), життєздатність визначали методом проточної цитометрії на лазерному цитофлюориметрі-сортері FACSAria («Becton Dickinson», США) після інкубації суспензії клітин із 7-аміноактиноміцином. Частка

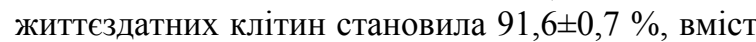
Nestin-позитивних клітин - 96 $\pm 0,5 \%$. У подальшому НСК культивували у багатокомпонентному середовищі (96 \% Neurobasal, 2 \% B-27 Supplement, $1 \%$ Glutamax, 0,1\% Sodium-pyruvate, $0,1 \%$ NAC, 0,5 \% пеніцилін/стрептоміцин - "Gibco", Велика Британія) у наявності 10 нМ фактору росту фібробластів 2 ("Sigma", США), через п’ять діб у середовище укладали фрагменти NeuroGel $^{\mathrm{TM}}$, розміром $16 \mathrm{mм}^{3}$, і культивували протягом 10 діб, до моменту трансплантації.

Модель спінальної травми - лівобічне пересічення половини поперечника спинного мозку на рівні $\mathrm{T}_{11}$ [1]. Оперативні втручання здійснювали в умовах загального знеболення (внутрішньоочеревинне введення суміші розчинів ксилазину ["Sedazin", "Biowet", Польща; 15 мг/кг] $i$ кетаміну ["Calypsol", "Гедеон Ріхтер А.O.", Угорщина; 70 мг/кг]), після нанесення травми спинного мозку у тварин групи "нейрогель+ НСК" у рану спинного мозку імплантували фрагмент NeuroGel ${ }^{\mathrm{TM}}$, асоційований із НСК, розміром $\sim 2 \mathrm{mм}^{3}$, у тварин групи "нейрогель" - фрагмент нативного NeuroGel ${ }^{\mathrm{TM}}$ аналогічного розміру. У тварин усіх експериментальних груп вікно доступу в хребтовий канал прикривали фрагментом підшкірної фасції, м'які тканини та шкіру з'єдну-

\footnotetext{
${ }^{1}$ European Communities Council Directives of 24 November 1986 (86/609/EEC), Свропейської Конвеції про захист хребетних тварин, які використовуються для експериментальних та наукових цілей (1986) та Закону України №3447-IV «Про захист тварин від жорстокого поводження» (21.20.2006)
} 
вали крученими поліамідними хірургічними нитками (ум. № 1, ПАТ "Київхімволокно") у два ряди вузлових швів, ділянку рани обробляли 5 \% спиртовим розчином йоду. У задню шийну ділянку підшкірно вводили розчин біциліну-5 (ПАТ "Киівмедпрепарат"; 150-200 тис ОД на 1 тварину), внутрішньоочеревинно - розчин дексаметазону (KRKA, Словенія; 6 мг/кг). Після вказаних маніпуляцій тварин протягом 2-4 годин утримували в приміщенні з підвищеною температурою повітря $\left(30^{\circ} \mathrm{C}\right)$, надалі - у клітках по 3-6 особин при середній температурі $21-24^{\circ} \mathrm{C}$.

Обмеження спонтанної локомоторної активності досягали шляхом утримання тварин підгрупи "нейрогель+НСК(мк)" протягом усього періоду спостереження в клітках із розмірами 30$\times 20 \times 10$ см (довжина $\times$ ширина $\times$ висота). Тварин підгрупи "нейрогель+НСК(вк)", груп "контроль" та "нейрогель" утримували в клітках розміром $40 \times 30 \times 15 \mathrm{~cm}$.

Показник функції (ПФ) задньої іпсилатеральної щодо зони травми кінцівки (ЗIK) визначали згідно зі шкалою D.M. Basso, M.S. Beattie та J.C. Bresnahan (BBB) $[1,6]$, показник спастичності (ПС) на рівні надп'ятково-гомілкового та колінного суглобів ЗІК - за шкалою В. Ashworth [2]. Протягом перших двох місяців ПФ та ПС ЗІК реєстрували наприкінці кожного тижня, у подальшому - наприкінці кожного місяця. Максимальний термін спостереження у всіх групах складав 28 тижнів, тварин виводили 3 експерименту шляхом передозування вказаних вище наркотичних препаратів.

Статистичну обробку даних здійснювали за допомогою програмного пакета STATISTICA 10.0 , для встановлення достовірності різниці середніх значень ПФ ЗІК між групами використовували U-тест Мана-Уітні (Mann-Whitney U-test), результати оцінки достовірності представляли у вигляді значень показника $\boldsymbol{p}$. Достовірність змін середніх значень ПФ ЗІК у межах групи впродовж експерименту оцінювали за методом Уілкоксона (Wilcoxon), представляли у вигляді значень показника $\boldsymbol{p}$. Кореляцію між значеннями ПС та ПФ ЗІК тварин групи на кожному з термінів спостереження, кожної тварини на різних термінах спостереження, а також середніх по групі значень ПФ і ПС ЗІК впродовж періоду спостереження оцінювали за допомогою непараметричного коефіцієнта рангової кореляції Спірмена (Srearman), результати оцінки виражали у вигляді значення коефіцієнта $\boldsymbol{r}$.

Результати дослідження та їх обговорення. Динаміка ПФ ЗІК у групі "контроль" (рис. 1) характеризується двофазністю: протягом 1-го місяця відмічали значуще збільшення ПФ ЗІК до $1,7 \pm 0,5$ бала ВВВ, яке після недостовірного регресу (5-8-ий тиждень), змінювалося вторинним збільшенням (12-16-й тиждень, $p<0,05$ при порівнянні ПФ ЗІК на 16-му та 8-му тижні) та стабілізацією. Станом на 28-й тиждень спостереження ПФ ЗІК склав $1,6 \pm 0,5$ бала ВВВ.
У групі "нейрогель" (рис. 1) значуще $(\mathrm{p} \leq 0,001)$ збільшення ПФ ЗІК спостерігали протягом 1-3-го та 6-12-го тижня, з 16-го тижня - стабілізацію. ПФ ЗІК станом на 28-й тиждень склав $8,4 \pm 0,9$ бала ВВВ.

У групі "нейрогель+НСК" станом на 7-му добу експерименту ПФ ЗІК склав 4,0土0,6 бала $\mathrm{BBB}$, достовірно перевищував показники груп "контроль" та "нейрогель". Протягом наступних двох тижнів спостерігали лінійне збільшення, починаючи з 4-го тижня - стабілізацію ПФ ЗІК, яка змінювалася спершу повільним, у подальшому - інтенсивним значущим збільшенням ПФ ЗІК

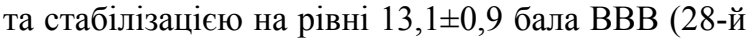
тиждень).

Динаміка ПФ ЗІК у підгрупі "нейрогель+НСК(вк)" характеризувалася наявністю двох фаз: протягом 2-3-го тижня та 8-16-го тижня спостерігали значуще збільшення, протягом 5-го тижня короткотермінове - значуще зменшення показника. Динаміка ПФ ЗІК у підгрупі "нейрогель+НСК(мк)" схожа, однак перша фаза достовірно довша (2-4-й тиждень), друга - коротша (8-12-й тиждень). Станом на 28-й тиждень спостереження ПФ ЗІК у підгрупі "нейрогель+НСК(мк)" - 12,6 1 1,4 бала, у підгрупі "нейрогель+НСК(вк)" - 13,7 $\pm 0,8$ бала ВBВ.

Протягом усього періоду спостереження ПФ ЗІК групи "нейрогель+НСК", підгруп "нейрогель+НСК(вк)" та "нейрогель+НСК (мк)" достовірно перевищував показник групи "контроль" $(\mathrm{p}<0,001)$. ПФ ЗІК групи "нейрогель" достовірно перевищував показник групи "контроль" упродовж 2-28-го тижня спостереження $\left(\mathrm{p}<4 \cdot 10^{-5}\right)$. ПФ ЗІК групи "нейрогель+НСК" достовірно перевищував показник групи "нейрогель" станом на 7-му добу та протягом 5-28-го тижня спостереження. ПФ ЗІК підгрупи "нейрогель+НСК(вк)" достовірно перевищував показник групи "нейрогель" станом на 7-му добу та протягом 12-28-го тижня, ПФ ЗІК підгрупи "нейрогель+НСК(мк)" - станом на 5-й тиждень та протягом 16-28-го тижня спостереження. Максимальну різницю між ПФ ЗІК обох підгруп виявляли протягом 1-3-го тижня $(\mathrm{p}=0,17 ; \mathrm{p}=0,12 ; \mathrm{p}=0,2$, відповідно).

Максимальне збільшення $(\mathrm{p}<0,05)$ ПС ЗІК у групі "контроль" спостерігали протягом 1-го місяця (рис. 2); протягом 6-8-го тижня відмічали повільніше лінійне збільшення, протягом 5-го місяця - значуще збільшення, у подальшому недостовірне зменшення до 2,5 $\pm 0,4$ бала Ashworth.

Перший період значущого $(\mathrm{p} \leq 0,005)$ приросту ПС ЗІК у групі "нейрогель" виявляли на 3-му тижні, другий - протягом 7-го тижня, третій протягом 5-го місяця. Станом на 28-й тиждень

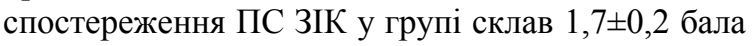
Ashworth.

Станом на 7-му добу ПС ЗІК у групі "нейрогель+НСК" склав $0,8 \pm 0,1$ бала Ashworth, достовірно переважав показник групи 


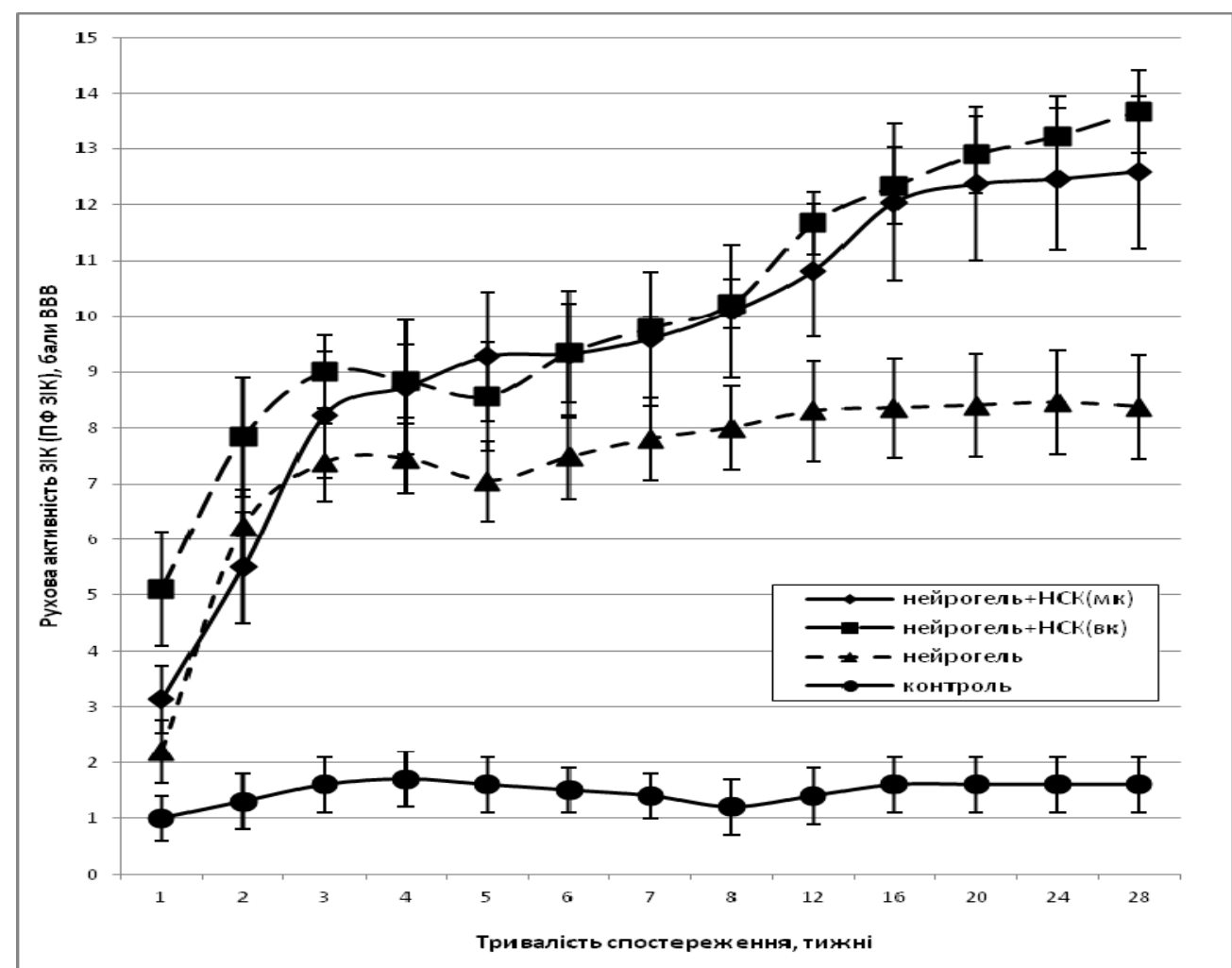

Рис. 1. Динаміка середнього показника функції задньої іпсилатеральної місцю травми кінцівки (ПФ ЗІК) у експериментальних групах

Примітка: терміни спостереження, на яких різниця ПФ ЗІК між наведеними групами значуща, вказані у тексті

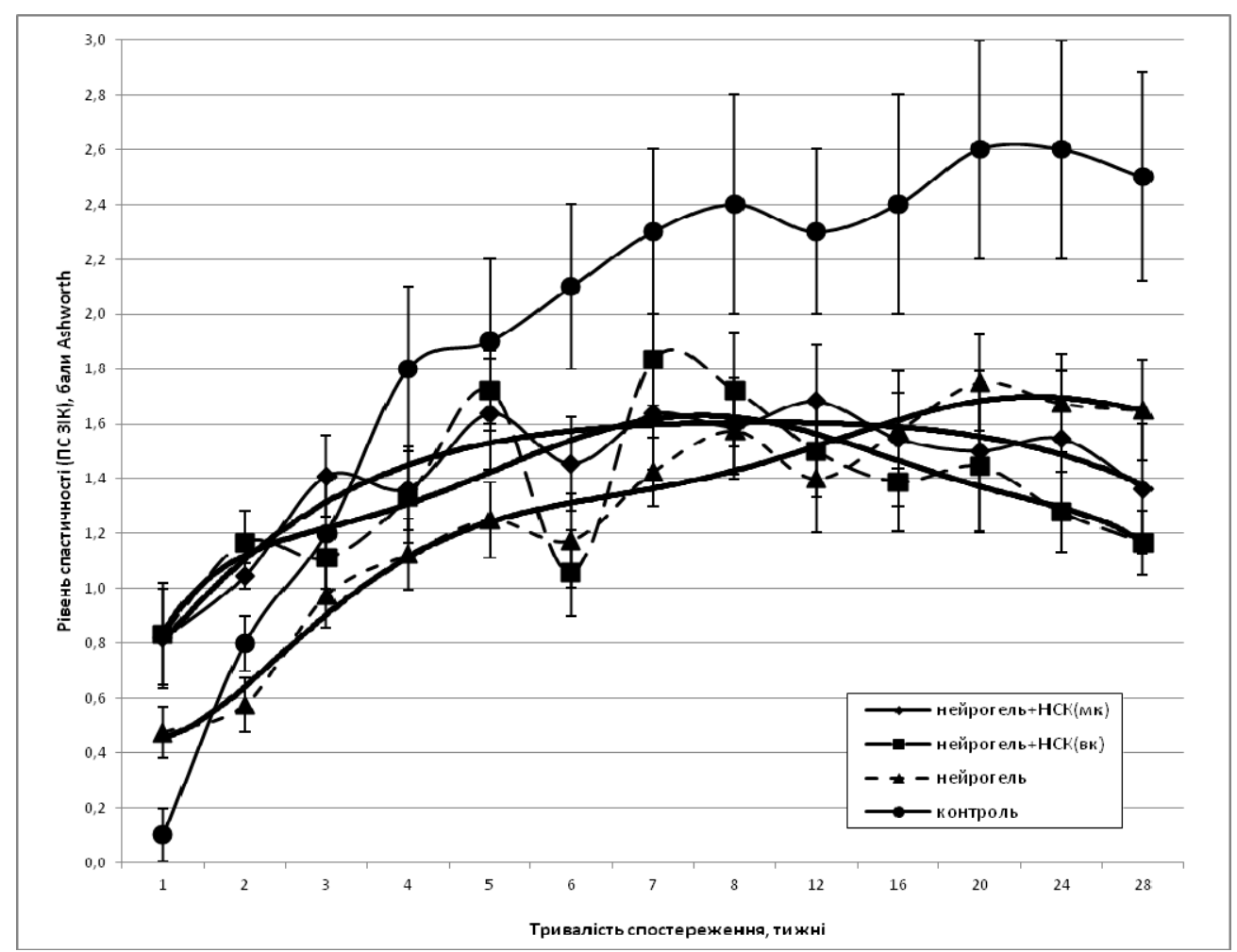

Рис. 2. Динаміка середнього показника спастичності задньої іпсилатеральної місцю травми кінцівки (ПФ ЗІК) в експериментальних групах. Для групи "нейрогель" та підгруп "нейрогель+НСК(вк)" та "нейрогель+НСК(мк)" додано лінію тренду - графічний вираз поліномальної апроксимації ряду даних (міра поліному - 6). Терміни спостереження, на яких різниця ПС ЗІК між наведеними групами значуща, вказані у тексті 
"контроль" ( $\mathrm{p}=0,0002)$ та "нейрогель" $(\mathrm{p}=0,03)$. Значуще збільшення ПС ЗІК реєстрували протягом 3-5-го тижня; протягом 8-28-го тижня спостерігали повільне значуще зменшення до $1,3 \pm 0,1$ бала Ashworth.

Динаміка ПC ЗІК у підгрупі "нейрогель+НСК(вк)" включає фазу значущого збільшення до кінця 7-го тижня $(1,8 \pm 0,2$ бала Ashworth; найбільш інтенсивний приріст на 5-му тижнi, $p=0,03)$ та фазу значущого зменшення до кінця експерименту $(1,2 \pm 0,1$ бала Ashworth, найбільи інтенсивне протягом 4-, 6-го та 7-го місяuя). Динаміка ПС ЗІК у підгрупі "нейрогель+ НСК(мк)" відрізняється коротшою першою фазою, під час якої спостерігали значуще й інтенсивніше збільшення ПС ЗІК (3-й тиждень) і відсутністю другої фази. Станом на 28-й тиждень спостереження ПС ЗІК підгрупи "нейрогель +НСК (вк)" - 1,2 $\pm 0,1$ бала, підгрупи "нейрогель+НСК

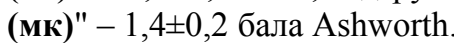

Різницю $(p<0,05)$ значень ПС ЗІК між групами "нейрогель" та "контроль" відмічали на 1му, 5-7-му та 12-24-му тижні; між групами "нейрогель+НСК" та "контроль" - на 1-2-му, 67-му та 16-28-му тижні, між групами "нейрогель+НСК" та "нейрогель" - на 1-2-му та 5-му тижні, між підгрупою "нейрогель+НСК (вк)" та групою "нейрогель" - на 2-му і 5-му тижні, між підгрупою "нейрогель+НСК(мк)" та групою "нейрогель" - на 2-му тижні. Різниця значень ПС ЗІК підгруп "нейрогель+НСК(вк)" та "нейрогель+НСК(мк)" протягом періоду спостереження недостовірна.

\section{Висновки}

1. Обмеження спонтанної локомоторної активності після спінальної травми сповільнює відновлення рухової функції протягом гострого, раннього та проміжного періоду, а також скорочує тривалість фази значущого відновлення протягом віддаленого періоду травматичного процесу.

2. Ксенотрансплантація нейрогенних стовбурових клітин у комплексі $з \mathrm{NeuroGel}^{\mathrm{TM}}$ призводить до значущого збільшення мимовільного м'язового тонусу протягом 1-2-го тижня травматичного процесу, з тенденцією до зменшення протягом віддаленого періоду.

3. Обмеження спонтанної локомоторної активності призводить до достовірного пришвидшення розвитку синдрому спастичності та формування стійкої його форми; лібералізація локомоторної активності зумовлює сповільнення росту спастичності в ранньому та проміжному періоді травми, а також значущий іiі регрес у віддаленому періоді.

Напрямки подальших досліджень. Визначення механізмів позитивного впливу апробованих у даному дослідженні засобів відновного лікування травми спинного мозку потребує подальших досліджень із залученням електрофізіологічного, молекулярно-генетичного та імуногістохімічного методів.

\section{Література}

1. Модель пересічення половини поперечника спинного мозку. I. Технічні, патоморфологічні та клінікоекспериментальні особливості / B.I. Цимбалюк, В.В. Медведєв, В.М. Семенова [та ін.] // Укр. нейрохірург. ж. - 2016. - № 2. - С. 18-27.

2. Модель поперечного пересічення половини спинного мозку. Частина II. Стан нервово-м'язового апарату, синдром посттравматичної спастичності та хронічний больовий синдром / В.І. Цимбалюк, В.В. Медведєв, Н.Я. Гридіна [та ін.] // Укр. нейрохірург. ж. - 2016. № 3. - С. 9-17.

3. Цимбалюк В.I. Реконструктивно-відновна хірургія спинного мозку / В.І. Цимбалюк, Ю.Я. Ямінський. К.: Авіцена, 2009. - 248 с.

4. Цымбалюк В.И. Спинной мозг. Элегия надежды: монография / В.И. Цымбалюк, В.В. Медведев. - Винница: Нова Книга, 2010. - 944 с.

5. Adrenergic receptors modulate motoneuron excitability, sensory synaptic transmission and muscle spasms after chronic spinal cord injury / M.M. Rank, K.C. Murray, M.J. Stephens [et al.] // J. Neurophysiol. - 2011. Vol. 105, № 1. - P. 410-422.

6. Basso D.M. A sensitive and reliable locomotor rating scale for open field testing in rats / D.M. Basso, M.S. Beattie, J.C. Bresnahan // J. Neurotrauma. - 1995. Vol. 12, № 1. - P. 1-21

7. Boakye M. Quality of life in persons with spinal cord injury: comparisons with other populations / M. Boakye, B.C. Leigh, A.C. Skelly // J. Neurosurg. Spine. - 2012. Vol. 17. - P. 29-37.

8. Changes in locomotor muscle activity after treadmill training in subjects with incomplete spinal cord injury / M.A. Gorassini, J.A. Norton, J. Nevett-Duchcherer [et al.] // J. Neurophysiol. - 2009. - Vol. 101, № 2. - P. 969-979.

9. Control of an ambulatory exoskeleton with a brainmachine interface for spinal cord injury gait rehabilitation / E. López-Larraz, F. Trincado-Alonso, V. Rajasekaran [et al.] // Front. Neurosci. - 2016. - Vol. 10, Article 359. - P. 1-15.

10. DeVivo M.J. Epidemiology of traumatic spinal cord injury: trends and future implications / M.J. DeVivo // Spinal Cord. - 2012. - Vol. 50, № 5. - P. 365-372.

11. Down-regulation of the potassium-chloride cotransporter KCC2 contributes to spasticity after spinal cord injury / P. Boulenguez, S. Liabeuf, R. Bos [et al.] // Nat. Med. 2010. - Vol. 16, № 3. - P. 302-307.

12. Effects of 6 months of regular passive movements on ankle joint mobility in people with spinal cord injury: a randomized controlled trial / L.A. Harvey, R.D. Herbert, J. Glinsky [et al.] // Spinal Cord. - 2009. - Vol. 47, № 1. P. 62-66.

13. Expression of heat shock protein (HSP)-25 and HSP-32 in the rat spinal cord reconstructed with Neurogel / S. Woerly, O. Awosika, P. Zhao [et al.] // Neurochem. Res. 2005. - Vol. 30, № 6-7. - P. 721-735.

14. Fouad K. Rehabilitative training and plasticity following spinal cord injury / K. Fouad, W. Tetzlaff // Exp. Neurol. - 2012. - Vol. 235. - P. 91-99.

15. Gait speed using powered robotic exoskeletons after spinal cord injury: a systematic review and correlational study / D.R. Louie, J.J. Eng, T. Lam, SCIRE Research Team // J. Neuroeng. Rehabil. - 2015. - Vol. 12, Article 82. - P. 1-10.

16. Hydrogels and cell based therapies in spinal cord injury regeneration / R.C. Assunção-Silva, E.D. Gomes, N. Sousa [et al.] // Stem Cells International. - 2015. Vol. 2015, Article 948040. - P. 1-24.

17. Increase in the excitability of spinal inhibitory pathways from intensive locomotor training after incomplete spinal cord injury / E.T. Zewdie, F.D. Roy, J. Yang [et al.] // Clin. Neurophysiol. - 2011. - Vol. 122, Suppl. 177. P. 22-25, doi: 10.1016/S1388-2457(11)60641-X. 
18. Knikou M. Locomotor training improves premotoneuronal control after chronic spinal cord injury / M. Knikou, C.K. Mummidisetty // J. Neurophysiol. - 2014. Vol. 111, № 11. - P. 2264-2275.

19. Knikou M. Neural control of locomotion and traininginduced plasticity after spinal and cerebral lesions / M. Knikou // Clin. Neurophysiol. - 2010. - Vol. 121, № 10. - P. 1655-1668.

20. Life expectancy after spinal cord injury: a 50-year study / J.W. Middleton, A. Dayton, J. Walsh [et al.] // Spinal Cord. - 2012. - Vol. 50, № 11. - P. 803-811.

21. Miller L.E. Clinical effectiveness and safety of powered exoskeleton-assisted walking in patients with spinal cord injury: systematic review with metaanalysis / L.E. Miller, A.K. Zimmermann, W.G. Herbert // Med. Devices (Auckl). - 2016. - Vol. 9. - P. 455-466.

22. Nogo-A antibodies and training reduce muscle spasms in spinal cord-injured rats / R.R. Gonzenbach, P. Gasser, B. Zörner [et. al.] // Ann. Neurol. - 2010. - Vol. 68, № 1. - P. 48-57.

23. Odeen I. Evaluation of the effects of muscle stretch and weight loading patients with spastic paraplegia / I. Odeen, E. Knutsson // Scand. J. Rehabil. Med. - 1981. - Vol. 13, № 4. - P. 117-121.

24. Polysynaptic excitatory postsynaptic potentials that trigger spasms after spinal cord injury in rats are inhibited by 5-HT1B and 5-HT1F receptors / K.C. Murray, M.J. Stephens, M. Rank [et al.] // J. Neurophysiol. - 2011. - Vol. 106, № 2. - P. 925-943.

25. Prevention of gliotic scar formation by NeuroGel allows partial endogenous repair of transected cat spinal cord / S. Woerly, V.D. Doan, N. Sosa [et al.] // J. Neurosci. Res. - 2004. - Vol. 75, № 2. - P. 262-272.

26. Quality of life after spinal cord injury: a comparison across six countries / S. Geyh, C. Ballert, A. Sinnott [et al.] // Spinal Cord. - 2013. - Vol. 51, № 4. - P. 322-326.

27. Reconstruction of the transected cat spinal cord following NeuroGel implantation: axonal tracing, immunohistochemical and ultrastructural studies / S. Woerly, V.D. Doan, N. Sosa [et al.] // Int. J. Dev. Neurosci. 2001. - Vol. 19, № 1. - P. 63-83.

28. Recovery of neuronal and network excitability after spinal cord injury and implications for spasticity / J.M. D'Amico, E.G. Condliffe, K.J. Martins [et al.] // Front. Int. Neurosci. - 2014. - Vol. 8, Article 36. - P. 1-24.

29. Short-term maximal-intensity resistance training increases volitional function and strength in chronic incomplete spinal cord injury: a pilot study / A. Jayaraman, C.K. Thompson, W.Z. Rymer, T.G. Hornby // J. Neurol. Phys. Ther. - 2013. - Vol. 37, № 3. - P. 112-117.

30. Siebert J.R. Biomaterial approaches to enhancing neurorestoration after spinal cord injury: strategies for overcoming inherent biological obstacles / J.R. Siebert, A.M. Eade, D.J. Osterhout // BioMed Res. Int. - 2015. Vol. 2015, Article 752572. - P. 1-20.

31. Spinal cord reconstruction using NeuroGel implants and functional recovery after chronic injury / S. Woerly, V.D. Doan, F. Evans-Martin [et al.] // J. Neurosci. Res. 2001. - Vol. 66, № 6. - P. 1187-1197.

32. Spinal cord repair with PHPMA hydrogel containing RGD peptides (NeuroGel) / S. Woerly, E. Pinet, L. de Robertis [et al.] // Biomaterials. - 2001. - Vol. 22, № 10. - P. 1095-1111.

33. Starkey M.L. Anti-Nogo-A and training: can one plus one equal three? / M.L. Starkey, M.E. Schwab // Exp. Neurol. - 2012. - Vol. 235. - P. 53-61.

34. The effect of electrical passive cycling on spasticity in war veterans with spinal cord injury / S.M. Rayegani, H. Shojaee, L. Sedighipour [et al.] // Front. Neurol. 2001. - Vol. 2, Article 39. - P. 1-7, doi: 10.3389/ fneur.2011.00039.

35. The effects of stretching in spasticity: a systematic review / T.J. Bovend'Eerdt, M. Newman, K. Barker [et al.] // Arch. Phys. Med. Rehabil. - 2008. - Vol. 89, № 7. P. 1395-1406.

36. Trajectories of life satisfaction after spinal cord injury / C.R. Pretz, A.J. Kozlowski, Y. Chen [et al.] // Arch. Phys. Med. Rehabil. - 2016. - May 27, [Epub ahead of print], doi: 10.1016/j.apmr.2016.04.022.

37. Tsintou M. Advances in regenerative therapies for spinal cord injury: a biomaterials approach / M. Tsintou, K. Dalamagkas, A.M. Seifalian // Neural Regen. Res. 2015. - Vol. 10, № 5. - P. 726-742.

38. Using extracellular matrix for regenerative medicine in the spinal cord [Text] / F.Z. Volpato, T. Führmann, C. Migliaresi [et al.] // Biomaterials. - 2013. - Vol. 34, № 21. - P. 4945-4955.

39. Walking with a powered robotic exoskeleton: Subjective experience, spasticity and pain in spinal cord injured persons / G. Stampacchia, A. Rustici, S. Bigazzi [et al.] // NeuroRehabil. - 2016. - Vol. 39, № 2. - P. 277-283, doi: 10.3233/NRE-161358.

\section{ВЛИЯНИЕ ОГРАНИЧЕНИЯ СПОНТАННОЙ ЛОКОМОТОРНОЙ АКТИВНОСТИ НА ТЕЧЕНИЕ СИНДРОМА СПАСТИЧНОСТИ ПРИ ЭКСПЕРИМЕНТАЛЬНОЙ ТРАВМЕ СПИННОГО МОЗГА И ИМПЛАНТАЦИИ МАТРИКСА NEUROGEL ${ }^{\mathrm{TM}}$, АССОЦИИРОВАННОГО С НЕЙРОГЕННЫМИ СТВОЛОВЫМИ КЛЕТКАМИ}

\section{В.И. Козявкин ${ }^{1}$ В.И. Цымбалюк ${ }^{2}$ В.В. Медведев ${ }^{3}$, О.А. Рыбачук ${ }^{4,5}$, Н.Г. Драгунцова ${ }^{2}$}

Резюме. Цель: изучить влияние имплантации $\mathrm{NeuroGel}^{\mathrm{TM}}$, ассоциированного с нейрогенными стволовыми клетками (НСК), в сочетании с либерализацией спонтанной локомоторной активности на восстановление двигательной функции и динамику спастичности паретичной задней конечности крысы после травмы спинного мозга.

Материал и методы. Животные - белые беспородные крысы-самцы (5 мес., 250 г); группы: 1 - травма спинного мозга $(n=16) ; 2$ - травма спинного мозга + гомотопическая имплантация фрагмента $\operatorname{NeuroGel}^{\mathrm{TM}}(n=20) ; 3-$ травма спинного мозга + гомотопическая имплантация фрагмента NeuroGel ${ }^{\mathrm{TM}}$, ассоциированного с НСК фетального гиппокампа мыши $(n=20)$. Группа 3 включала подгруппу $3_{\text {мк }}(\mathrm{n}=11)$, животных которой в течении эксперимента содержали в клетках малого размера $(30 \times 20 \times 10 \mathrm{~cm})$, и подгрупу $3_{\text {бк }}(\mathrm{n}=9)$, животных которой содержали в клетках большого размера $(40 \times 30 \times 15 \mathrm{~cm})$. Модель травмы - левостороннее пересечение половины спинного мозга на уровне $\mathrm{T}_{11}$; длительность наблюдения - 28 нед.; оценка показателя функции (ПФ) и показателя спастичности (ПС) задней ипсилатеральной конечности (ЗИК) - шкала Basso-Beattie-Bresnahan (BBB) и Ashworth, соответственно.

Результаты. Ограничение спонтанной локомоторной активности замедляет восстановление двигательной функции паретичной конечности в течении 1-го месяца, сокращает длительность достоверного восстановления в отдаленном периде травмы. По состоянию на 28 -ую неделю наблюдения ПФ ЗИК в группе $1-1,6 \pm 0,5$ балла ВВВ, в группе $2-8,4 \pm 0,9$ балла, в группе $3-13,1 \pm 0,9$ балла, в подгруппе $3_{\text {мк }}-12,6 \pm 1,4$ балла, в подгруппе 3 бк $-13,7 \pm 0,8$ бала ВВВ. ПС ЗИК на этом сроке в группе $1-2,5 \pm 0,4$ балла, в группе $2-1,7 \pm 0,2$ балла, в группе $3-1,3 \pm 0,1$ балла, 
в подгруппе $3_{\text {мк }}-1,4 \pm 0,2$ балла, в подгруппе $3_{\text {бк }}-1,2 \pm 0,1$ балла Ashworth. Достоверную разницу значений ПС ЗИК между группами 2 и 1 отмечали на 7-ые сутки, 5-7-ой и 12-24-ой неделе, между группами 3 и 1 - на 1-2-ой, 6-7-ой и 16-28-ой неделе, между группами 3 и 2 - на 1-2-ой и 5-ой неделе, между подгруппой 3 бк и группой 2 - на 2 -ой и 5 -

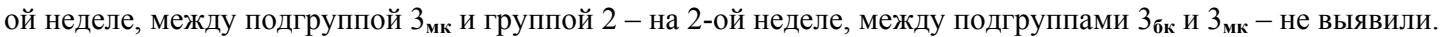

Вывод. Ограничение спонтанной локомоторной активности животных в условиях тканево-инженерного восстановительного вмешательства после спинальной травмы усложняет течение регенерационного процесса, ускоряет формирование стойкого синдрома спастичности.

Ключевые слова: травма спинного мозга, синдром спастичности, восстановительная нейрохирургия, тканевая нейроинженерия, физическая реабилитация.

\section{THE EFFECT OF SPONTANEOUS LOCOMOTOR ACTIVITY RESTRICTION ON THE COURSE OF SPASTICITY SYNDROME AFTER SPINAL CORD INJURY AND NEUROGEL ${ }^{\text {TM }}$ ASSOCIATED WITH NEURAL STEM CELLS IMPLANTATION}

\section{V.I. Kozyavkin ${ }^{1}$, V.I. Tsymbaliuk ${ }^{2}$, V.V. Medvediev ${ }^{3}$, O.A. Rybachuk ${ }^{4,5}$, N.G. Draguntsova ${ }^{2}$}

Abstract. Objective: To examine the effect of NeuroGel ${ }^{\mathrm{TM}}$ and xenogenic fetal neural stem cells (NSC) coimplantation coupled with the liberalization of spontaneous locomotor activity on the rat's hind limb motor function recovery and spastisity syndrome dynamic after experimental spinal cord injury.

Materials and methods. Animals: outbred albino rats (males, 5.5 months, $250 \mathrm{~g}$ ); experimental groups: 1 - spinal cord injury only $(\mathrm{n}=16) ; 2$ - spinal cord injury + immediate homotopical transplantation of NeuroGel ${ }^{\mathrm{TM}}(\mathrm{n}=20) ; 3-$ spinal cord injury + analogous transplantation of NeuroGel ${ }^{\mathrm{TM}}$ in association with fetal (E17) mouse NSC (n=12). Group 3 included a subgroup $3_{\mathrm{sc}}$, the animals of which $(\mathrm{n}=6)$ were kept in small cages $(30 \times 40 \times 10 \mathrm{~cm})$, and subgroup $3_{\mathrm{lc}}$, whose animals $(n=6)$ were kept in large cages $(40 \times 30 \times 15 \mathrm{~cm})$. Model of injury - left-side spinal cord hemisection at $\mathrm{T}_{11}$; the duration of observation - 28 weeks; monitoring of the ipsilateral hindlimb (IHL) function indicator (FI) and spasticity indicator (SI) - the Basso-Beattie-Bresnahan scale (BBB) and Ashworth scale, respectively.

Rersults. Restriction of spontaneous locomotor activity slows paretic limb motor function recovery during $1^{\text {st }}$ month, reduces the duration of significant recovery in the late period of injury. At the $28^{\text {th }}$ week of observation IHL FI in group 1 was $1,6 \pm 0,5$ points of $\mathrm{BBB}$, in group $2-8,4 \pm 0,9$ points , in group $3-13,1 \pm 0,9$ points , in subgroup $3_{\text {sc }}-12,6 \pm 1,4$ points , in subgroup $3_{\mathrm{lc}}-13,7 \pm 0,8$ points of BBB. At this term of observation IHL SI in group 1 was $2,5 \pm 0,4$ points of the Ashworth scale, in groupe $2-1,7 \pm 0,2$ points, in group $3-1,3 \pm 0,1$ points, in subgroup $3_{\text {sc }}-1,4 \pm 0,2$, in subgroup $3_{\text {lc }}-$ $1,2 \pm 0,1$ points of Ashworth scale. Significant difference of IHL SI values between group 2 and group 1 was found at the $7^{\text {th }}$ day, $5^{\text {th }}-7^{\text {th }}$ and $12^{\text {th }}-24^{\text {th }}$ week, between group 3 and group $1-$ at the $1^{\text {st }}-2^{\text {nd }}, 6^{\text {th }}-7^{\text {th }}$ and $16^{\text {th }}-28^{\text {th }}$ week, between group 3 and group 2 - at the $1^{\text {st }}-2^{\text {nd }}$ and $5^{\text {th }}$ week, between subgroup $3_{\mathrm{lc}}$ and group $2-$ at the $2^{\text {nd }}$ and $5^{\text {th }}$ week, between subgroup $3_{\text {sc }}$ and group 2 - at the $2^{\text {nd }}$ week, between subgroup $3_{\text {Ic }}$ and subgroup $3_{\text {sc }}$ - was not found.

Conclusion. Restriction of spontaneous locomotor activity in case of the tissue engineering-restorative intervention after spinal cord injury complicates the regeneration process, accelerates the formation of stable spasticity syndrome.

Key words: spinal cord injury, spasticity syndrome, restorative neurosurgery, tissue neuroengineering, physical rehabilitation.

${ }^{1}$ International Clinic of Rehabilitation (Truskavets)
${ }^{2}$ The state institution "Institute of neurosurgery n. after acad. A.P. Romodanov of NAMS of Ukraine" (Kyiv)
${ }^{3}$ Bogomoletz National Medical Universit (Kyiv)
${ }^{4}$ Bogomoletz Institute of Physiology, National Academy of Sciences of Ukraine (Kyiv)
${ }^{5}$ The state institution "Institute of genetic and regenerative medicine of NAMS of Ukraine" (Kyiv)

Рецензент - проф. В.Ф. Мислицький

Buk. Med. Herald. - 2016. - Vol. 20, № 4 (80). - P. 83-89

Надійшла до редакції 04.10.2016 року

(C) В.І. Козявкін, В.І. Цимбалюк, В.В. Медведєв, О.А. Рибачук, Н.Г. Драгунцова, 2016 